\title{
Regulation of spatial and seasonal variation of macroalgal biomass in a brackish, eutrophic lake
}

Received: 5 September 2001 / Revised: 22 May 2002 / Accepted: 12 June 2002 / Published online: 28 August 2002 (C) Springer-Verlag and AWI 2002

\begin{abstract}
Processes leading to biomass variation of Ulva were investigated at two contrasting sites in the eutrophic Veerse Meer (The Netherlands). Ulva species dominated at the Middelplaten site, while at the Kwistenburg site a mixture of Ulva spp. and Chaetomorpha linum dominated. Total summer macroalgal biomass was higher at Middelplaten than at Kwistenburg (282 and $79 \mathrm{~g} \mathrm{DW}$ $\mathrm{m}^{-2}$, respectively). Growth rates of Ulva spp. were high at both sites in May 1992 (cage mean 0.28-0.30 day-1), but quickly dropped to lower values $\left(0.05-0.10 \mathrm{day}^{-1}\right)$. In May, growth rates were significantly highest at Kwistenburg, while during the rest of the season growth rates were similar for both sites. Temperature, $\mathrm{pH}$, dissolved oxygen, salinity, light attenuation, phytoplankton and nutrient concentrations did not differ between sites. The relation between variation in Ulva spp. growth rates and environmental parameters was analysed using stepwise multiple regression, showing that light and temperature were the main variables regulating Ulva spp. growth rates. As Ulva growth rates were similar for both sites but biomass was much lower at Kwistenburg it was concluded that a large amount of produced biomass was lost at Kwistenburg. Although the exact reason for this remains unclear, it seems most likely that transport of macroalgae by wind and waves is a very important factor. This study shows the importance of simultaneously measuring
\end{abstract}

Communicated by K. Lüning

E.-j. Malta ( $)$ J.M. Verschuure

Netherlands Institute of Ecology,

Centre for Estuarine and Coastal Ecology,

PO Box 140, 4400 AC Yerseke, The Netherlands

e-mail: erih.malta@uca.es

Tel.: +34-956-016026, Fax: +34-956-016019

P.H. Nienhuis

Department of Environmental Studies, Faculty of Science,

University of Nijmegen, PO Box 9010, 6500 GL Nijmegen,

The Netherlands

Present address:

E.-j. Malta, Área de Ecología,

Facultad de Ciencias del Mar y Ambientales,

Universidad de Cádiz, 11510 Puerto Real, Cádiz, Spain growth rates and biomass at a high temporal resolution to reveal the mechanisms responsible for spatial variation in macroalgal biomass in shallow coastal areas.

Keywords Chaetomorpha linum - Growth · Loss processes - Spatial variation - Ulva

\section{Introduction}

One of the most conspicuous results of eutrophication in shallow coastal waters is the mass development of macroalgae. In general, the process of eutrophication leads to a shift in the macrophytobenthic community from slowgrowing seagrasses and macroalgae (for instance Fucus spp. and Pelvetia canaliculata) to phytoplankton and fast-growing macroalgae such as Ulva, Enteromorpha and Cladophora spp. (Sand-Jensen and Borum 1991; Duarte 1995). The high surface-area to volume ratio of these mass-forming macroalgae favours rapid nutrient uptake, high production and rapid growth rates, which enable them to outcompete the original vegetation (Littler and Littler 1980; Hein et al. 1995; Pedersen and Borum 1997). Eutrophication effects on the benthic vegetation of coastal waters are reviewed by Schramm and Nienhuis (1996) for Europe and by Thorne-Miller et al. (1983), Tewari and Joshi (1988), Brown et al. (1990) and Valiela et al. (1997) for other parts of the world.

The main processes of eutrophication have been intensely studied, in the field as well as in the laboratory. Conditions that determine the vulnerability of water bodies to eutrophication and the subsequent development of mass blooms are high nutrient loadings, a long residence time and reduced mixing with nutrient-poor (oceanic) waters (Morand and Briand 1996). However, the seasonal regulation of algal growth and biomass production, the mechanisms that lead to spatial variation in macroalgal biomass within one estuary or lagoon, and the interaction of these two are still poorly understood (Duarte 1995). Differences between sites in macroalgal biomass may be 
caused by differences in growth, by differences in loss processes (such as grazing) or a combination of these. Higher growth rates at one site imply that environmental conditions at that site are more favourable for macroalgal growth. Lack of differences in growth rates between sites but large differences in biomass imply that a large amount of biomass produced is lost. Hence, by simultaneously recording macroalgal growth rates, biomass and environmental data with a high temporal resolution (i.e. weekly to biweekly) it can be assessed whether growth or loss processes determine spatial variation in macroalgal distribution and how growth in its turn correlates to environmental parameters (Sfriso 1995; Hernández et al. 1997). Thus far, only few studies have addressed spatial variation in this way (Geertz-Hansen et al. 1993; Hernández et al. 1997; Sfriso and Marcomini 1997; Barthelemy et al. 2001).

Within the framework of the European EUMAC project (EUMAC 1994), eight European lagoons and estuaries were selected as model systems to study correlations between the temporal, seasonal and spatial variation in macrophyte biomass and species distribution and environmental variables. In a previous paper, Malta and Verschuure (1997) stressed the importance of light as the main variable responsible for the between-year variation in macroalgal biomass at the Dutch site (the Veerse Meer). Nitrogen was thought to be more important for the seasonal regulation of growth and biomass development. In this study, we compared two sites in the Veerse Meer, which differ with respect to macroalgal biomass and species distribution. The purpose of this study was to test whether growth or loss processes are responsible for these between-site differences and to analyse how growth rates correlate with environmental variables.

\section{Methods}

\section{Study area}

The study was conducted between March 1994 and March 1995 in the Veerse Meer, a shallow man-made, brackish (average salinity $=15-20 \mathrm{psu}$ ) lake situated in the southwestern part of the Netherlands (Fig. 1). The lake is non-tidal, but from October to April, the water level is lowered to $0.70 \mathrm{~m}$ below mean standard sea level in order to facilitate its function as a drainage basin: see Nienhuis $(1989,1992)$ and Coosen et al. (1990) for details on hydrography and hydrochemistry. We selected two sites for this study (Fig. 1) that were contrasting with respect to macroalgal species and biomass distribution (Hannewijk 1988; Van Lent and Verschuure 1994). The first site, Middelplaten, is representative of most of the shallow parts of the lake and is situated close to the islands called the Middelplaten, about 50-75 m from the gully. The second site is called Kwistenburg (4.5 km east of Middelplaten). It is bordering the main gully opposite to the sluices called the Zandkreeksluis. Water depth in summer in both sites is between 0.70 and $0.90 \mathrm{~m}$.

\section{Macroalgal parameters}

The sites were visited at 2-weekly intervals in April and October 1994, weekly from May to October 1994, and monthly from
November 1994 to April 1995. Biomass was determined by randomly taking three samples with a PVC cylinder $\left(\right.$ area $\left.=0.16 \mathrm{~m}^{2}\right)$. The Ulva spp. coverage in each cylinder sample was estimated visually and the biomass enclosed was collected, dried for $48 \mathrm{~h}$ at $60^{\circ} \mathrm{C}$ and weighed. To account for the patchy distribution of the algae (especially at Kwistenburg), it was decided to apply a correction factor to the coverage in the cylinder. For this purpose, a relatively large $(10 \times 10 \mathrm{~m})$ permanent quadrat $(\mathrm{PQ})$, which was considered representative for the site, was laid out at both sites. Weekly macroalgal coverage in the PQ was estimated visually with an underwater viewer. Biomass was corrected for PQ coverage as:

corrbiomass $\mathrm{m}^{-2}$ cylinder $=$ biomass $\mathrm{m}^{-2}$ cylinder

$\times$ (coveragePQ/coverage cylinder $)$

In this way, three independent estimates of PQ biomass were obtained for each site. Applying the correction factor had very little effect on the calculated biomass values at Middelplaten (where algal distribution was quite homogeneous); however, it did change the biomass values at Kwistenburg to what we feel were more reliable estimates of site biomass. This method was tested earlier in a very extensive mapping study of macroalgal biomass in the Veerse Meer and was found to give more reliable estimators of biomass, especially at sites where distribution was patchy (Hannewijk 1988).

Growth rates of the dominant species (Ulva spp.) were determined from May until the second week of October (last week of high water level) using cages. The cages, covering the whole water column, were vertically divided into three compartments in order to compare growth rates at different depths (see Malta and Verschuure 1997 for details). Each compartment contained five Ulva discs (42 mm diameter), punched from free-floating specimens with a sharpened stainless steel tube. Growth rate per compartment was calculated as the natural logarithm in weight increase:

growth rate $=\ln \left(W_{\mathrm{t}}-W_{0}\right) / t$

where $W_{0}$ is the initial and $W_{\mathrm{t}}$ the final dry weight after $t$ days of incubation. Fifteen discs were kept apart, weighed wet, dried for $48 \mathrm{~h}$ at $60^{\circ} \mathrm{C}$ and weighed again. From these discs a wet weight to dry weight conversion factor was determined (coefficient of variation was ranging from $1.5 \%$ to $3 \%$ ), which was applied to calculate the dry weight of the incubated discs. Five cages per site were used; the cages were cleaned every week. A correction was made for missing discs and discs that were heavily grazed upon $(3.9 \%$ and $0.5 \%$ of all incubated discs, respectively) by multiplying the initial weight by the number of discs found after 1 week divided by five, assuming that all discs had a similar weight. The amount of thallus removed by minor grazing was very small (less than $1 \mathrm{~mm}^{2}$ per disc) and was considered to be negligible. It can be argued that net growth rates (including grazing) may be more valuable than potential growth; however, considering the rare occurrence of heavy grazing and the point that flushing out of the cages is probably the most important loss factor, we felt that the correction was needed to prevent an underestimation of growth. The Discussion reviews the role of grazing in more detail.

We attempted to measure the growth rate of the other dominant alga at Kwistenburg, Chaetomorpha linum (O.F. Müll) Kütz. The algae were loosely wrapped in nylon nets, which were weighed wet before and after 1 week of incubation in the cages. However, only negative growth rates were found, probably due to biomass losses during the procedure. As we doubted the reliability of the method, we decided not to use these data.

Duplicate samples of algal material were dried for $48 \mathrm{~h}$ at $60^{\circ} \mathrm{C}$ and ground using a bullet mixer. The carbon and nitrogen content was determined on a Carlo-Erba NA 1500 CHN analyser. Phosphorus content was determined using the colorimetric procedure of Chen (1956), after tissue destruction with $\mathrm{HNO}_{3}-\mathrm{HCl}$ in a microwave oven (Nieuwenhuize and Poley-Vos 1989). Additionally, pieces of macroalgae were stored at $-80^{\circ} \mathrm{C}$ in tinfoil. The samples were freeze-dried and ground in a bullet mixer and tissue chlorophyll $a$ and $b$ were determined using reverse-phased HPLC 
Fig. 1 Location of the study area and the study sites

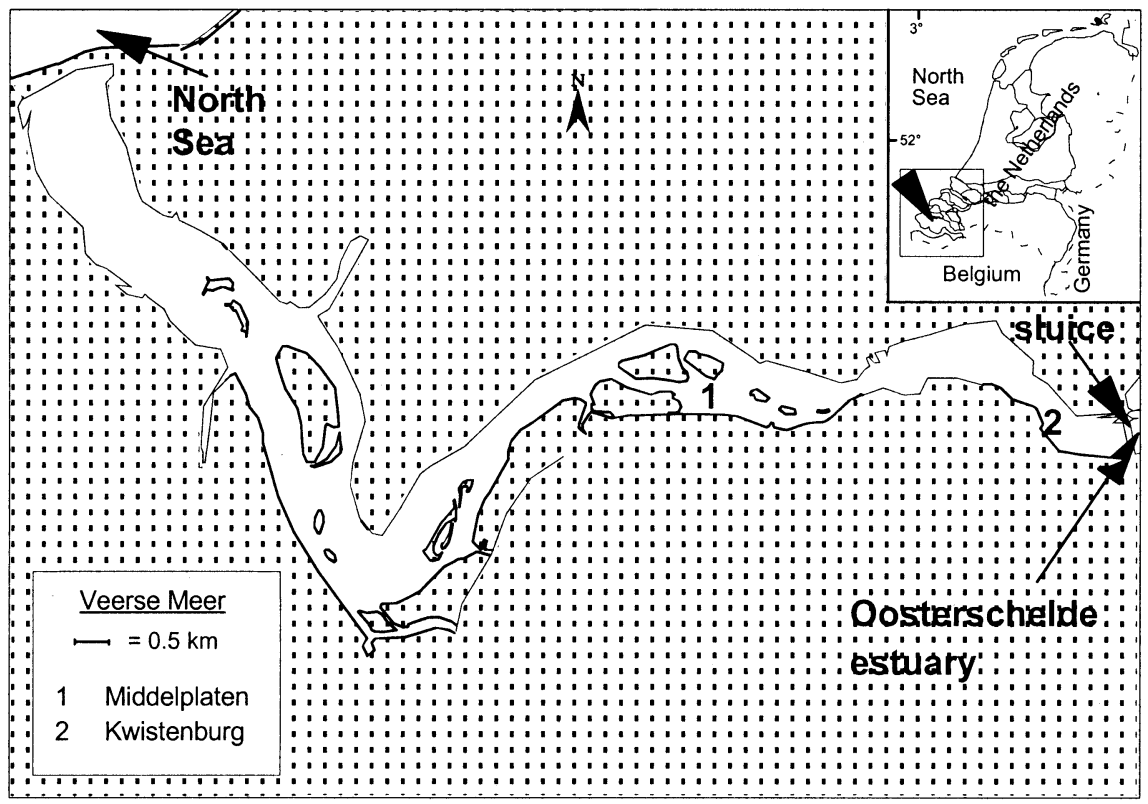

(Millipore Waters) according to Brown et al. (1981) after overnight extraction in the dark in a $90 \%$ acetone solution.

Water column parameters and light

During each visit, air and surface water temperature and weather conditions were recorded. Water samples were taken at mid-depth at each site with 1-litre PVC bottles and filtered over Schleicher \& Schuell No. 6 glass fibre filters that had been weighed before filtration. Two filters were dried for $48 \mathrm{~h}$ at $60^{\circ} \mathrm{C}$ and weighed after 20 min of cooling in a desiccator to determine the seston content. The other filters were stored in tinfoil at $-80^{\circ} \mathrm{C}$ and later extracted overnight in the dark in $90 \%$ acetone. The extract was analysed for chlorophyll $a$ and $b$ using reverse-phased HPLC (Millipore Waters) according to Brown et al. (1981). The water was analysed for nitrate+nitrite, ammonium and phosphate on a Skalar 5100 autoanalyzer and salinity was measured using a WTW microprocessor salinity meter mounted with a WTW KLE $1 /$ T electrode. At each visit, water samples $(n=5)$ were taken at mid-depth in bottles of approximately $100 \mathrm{ml}$ capacity (exact volume was determined by weighing with Aqua dest) and dissolved oxygen was determined using the Winkler titration method (Grasshof et al. 1983).

Hourly incident irradiance $\left(I_{0}\right)$ was measured with a LI-190SA quantum meter fitted with a PAR (400-700 nm) sensor, which was situated on top of the NIOO-CEMO building in Yerseke (approximately $30 \mathrm{~km}$ from the field sites). Light attenuation was measured at four depths in the Veerse Meer with a LiCor light meter, connected to a $2 \pi$ PAR $(400-700 \mathrm{~nm})$ photon sensor. Reflection was calculated as the difference between above- and just belowsurface irradiance. Because this method is sensitive to wave action, an overall average reflection of $11.7 \%( \pm 3.3)$ was used in the irradiance calculations. A weekly attenuation coefficient $(k)$ was calculated by averaging the attenuation coefficients for the four depths. Weekly incident irradiance $\left(I_{z}\right)$ at depth $z$ was then calculated using the Lambert-Beer equation (Jerlov 1970).

\section{Data analysis}

Differences between sites in water column parameters, light, weekly algal growth rates and chemical composition of the algae were examined for significance using a $t$-test. Water chlorophyll, seston, oxygen and nutrient concentrations and tissue nutrient concentrations were log-transformed in order to avoid heteroscedas- ticity (tested with a Bartlett test for homogeneity; Sokal and Rohlf 1995). Differences in growth rates among cage compartments were tested for significance using a one-way analysis of variance followed by a Tukey-Kramer a posteriori test where there was a significant ANOVA result. To detect relations between nutrient concentrations in the water and in the plant tissue, Pearson correlation coefficients were calculated. The degree of variation in weekly mean growth rate that can possibly be explained by the simultaneous effect of the environmental parameters (dissolved inorganic nitrogen, phosphate, salinity, temperature, light and tissue nutrient concentrations) was estimated using a multiple stepwise regression analysis (Sokal and Rohlf 1995). For the regression equation and further explanations, see the Results and Discussion sections. The data for the correlations and the multiple regressions were transformed in the same way as for the ANOVA and $t$-tests. In all cases, significance level was set at $5 \%$ probability.

\section{Results}

\section{Macroalgae parameters}

At Middelplaten, macroalgal biomass consisted almost entirely of two free-floating Ulva L. species: Ulva curvata (Kütz.) De Toni and Ulva scandinavica Bliding. Identification problems, resulting from taxonomic uncertainties (Malta et al. 1999) made a quantitative comparison of the relative contribution of each species to the total biomass impossible; therefore only total Ulva spp. biomass is be taken into account. At Kwistenburg, Ulva spp. dominated, together with Chaetomorpha linum. The Ulva biomass consisted of the same species as were found at Middelplaten. The biomass of other algae found at both sites was negligible (less than $1 \%$ of Ulva spp. and Ulva spp. and C. linum biomass at Middelplaten and Kwistenburg, respectively; data not shown).

Algae were completely absent from Middelplaten from January to April (Fig. 2A). Biomass build-up started in the second week of May and lasted for about 


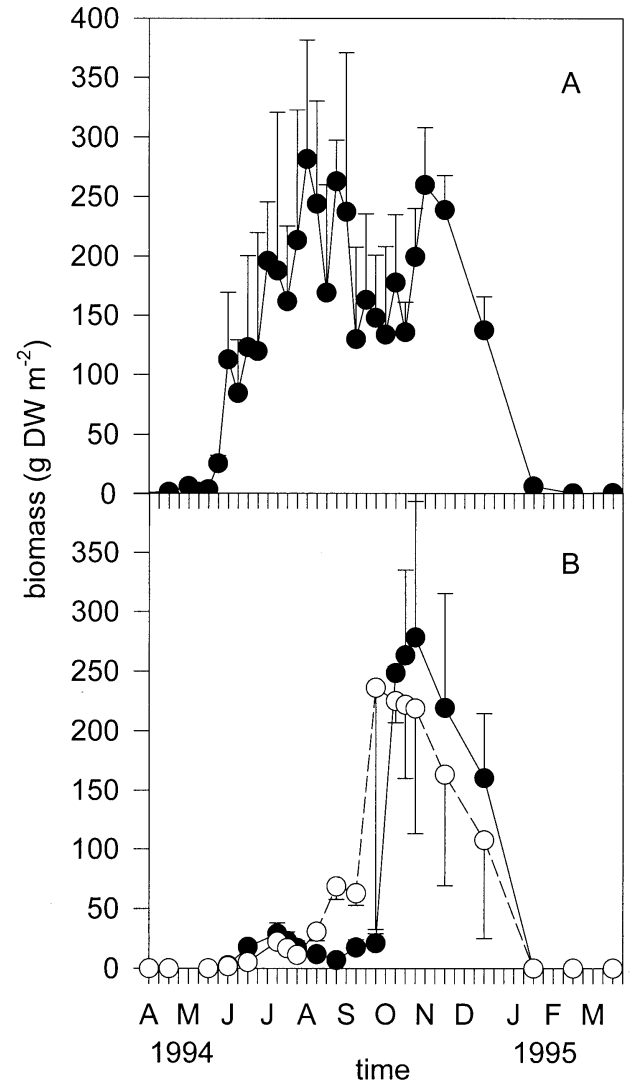

Fig. 2a, b Biomass values (g DW $\mathrm{m}^{-2}, n=3$ ) of macroalgae in the Veerse Meer (The Netherlands) from April 1994 until March 1995. A Biomass of Ulva spp. at the Middelplaten site; B biomass of Ulva spp. (closed circles, full line) and Chaetomorpha linum (open circles, dotted line) at the Kwistenburg site. Vertical lines on $x$-axis represent weeks. Error bars represent +1 SD for Ulva spp. and $-1 \mathrm{SD}$ for $C$. linum

10 weeks, when the maximum biomass was reached (282 $\mathrm{g} \mathrm{DW} \mathrm{m}^{-2}$ ). Four weeks later, biomass levels decreased to around $150 \mathrm{~g} \mathrm{DW} \mathrm{m}^{-2}$ and remained more or less stationary. At the end of October, a short increase was observed followed by a decomposition phase in which the biomass decreased and eventually disappeared completely. At Kwistenburg, biomass build-up started at the beginning of June (Fig. 2B). Compared to Middelplaten, total macroalgal biomass levels were low during summer (maximum in August $79 \mathrm{~g} \mathrm{DW} \mathrm{m}^{-2}$ ). At the end of September, biomass increased six-fold within a period of 2 weeks. Biomass distribution became very patchy in this period, as is illustrated by the high standard deviations. By the end of the year almost all the algae had disappeared from the site.

Initial growth rates of Ulva spp. at Middelplaten were high (cage mean $0.28-0.30$ day $^{-1}$ ) but decreased quickly after two weeks to a cage mean of 0.10 day $^{-1}$ in June (Fig. 3A) and remained relatively constant for the rest of the time (around 0.05 day $^{-1}$ ). At Kwistenburg Ulva growth rates were also high at the beginning of May and, overall, decreased after 2 weeks (Fig. 3B). However, the decline was less steep than at Middelplaten. Cage mean

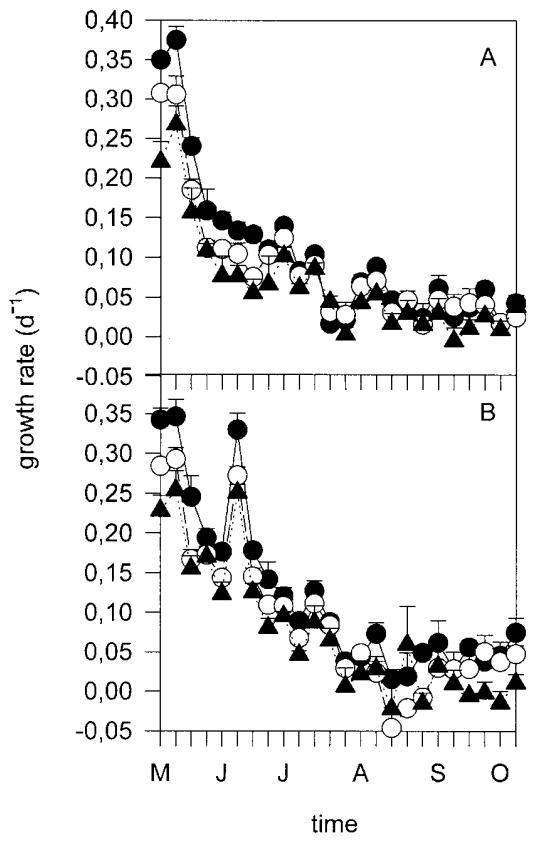

Fig. 3 Growth rates $\left(\right.$ day $\left.^{-1}, n=5\right)$ of Ulva spp. in 1994 in compartmented cages in the Veerse Meer (The Netherlands) at Middelplaten (A) and Kwistenburg (B). Growth rates of top compartment (dots, full line), middle compartment (circles, dotted line) and lower compartments (triangles, dotted lines). Error bars represent +1 SD. Vertical lines on $x$-axis represent weeks

growth rates were significantly higher at Kwistenburg than at Middelplaten during the last week of May, the first three weeks of June and in the third and fourth week of July ( $t$-test, $P<0.05-0.001)$. During the first week of July and the first, third and last week of August, growth rates were slightly, but significantly, higher at Middelplaten ( $t$-test, $P<0.05-0.001)$. For all other weeks, the differences were not significant. The mean annual growth rate was not significantly different between Middelplaten (0.086 day $\left.{ }^{-1}\right)$ and Kwistenburg $\left(0.096\right.$ day $\left.^{-1}\right)$. Testing between corresponding compartments gave the same results as testing between the cage means. As expected, growth rates were highest in the upper cage compartment (A) and lowest in the lowest compartment (C) with the middle compartment (B) having intermediate values at both sites (Fig. 3). Differences between A and $\mathrm{C}$ were always significant for both sites for most of the year (ANOVA, $P<0.05-0.001$ ).

Ulva spp. (Middelplaten) and C. linum (Kwistenburg) showed comparable trends in the seasonal cycles of tissue nitrogen $(\mathrm{N})$, carbon $(\mathrm{C})$ and phosphorus $(\mathrm{P})$ (Fig. 4A-C). Tissue $\mathrm{N}$ and $\mathrm{P}$ levels were high at the end of the winter and spring, decreased during biomass build-up and increased again after this period, eventually reaching their initial high levels during the decomposition phase. Tissue $\mathrm{C}$ pronounced a less obvious pattern in both species. Annual average tissue $\mathrm{C}$ was lower and tissue $\mathrm{P}$ was higher for C. linum than for Ulva spp. ( $t$-test, $P<0.001$ for both $\mathrm{C}$ and $\mathrm{P}$ ), while annual average tissue $\mathrm{N}$ levels were similar. A significant correlation 


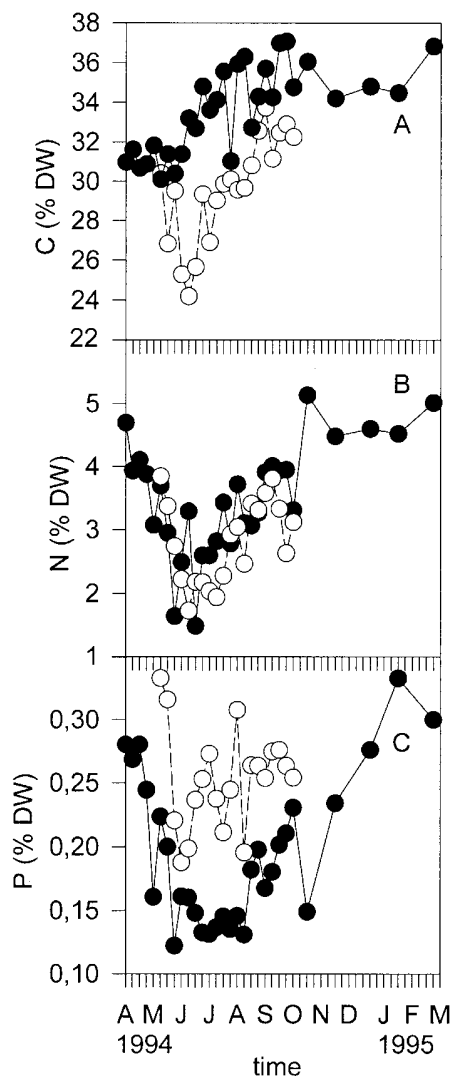

Fig. 4 Tissue carbon (A), nitrogen $(\mathbf{B})$ and phosphorus $(\mathbf{C})$ content (\% DW) of Ulva spp. at Middelplaten (closed circles, full line) and Chaetomorpha linum (open circles, dotted line) at the site Kwistenburg in the Veerse Meer (The Netherlands) from April 1994 until March 1995. Vertical lines on $x$-axis represent weeks

Table 1 Pearson correlation coefficients $(r)$ between different variables from the water and macrophytes at the two sampling sites (data from Figs. 2, 3, 4, 5 and 6 and from Table 2). Macroalgal data (tissue nutrients and pigments) are for Ulva spp. at Middelplaten and $C$. linum at Kwistenburg; $n=30$ for Middelplaten and $n=20$ for Kwistenburg

\begin{tabular}{llcc}
\hline & & $r$ (Middelplaten) & $r$ (Kwistenburg) \\
\hline DIN & DIP & $-0.64^{* * *}$ & $-0.47^{*}$ \\
Tissue N & DIN & $0.56^{* *}$ & $0.34 \mathrm{~ns}$ \\
Tissue P & DIP & $-0.50^{* *}$ & $-0.05 \mathrm{~ns}$ \\
Tissue N & Tissue P & $0.57^{* *}$ & $0.65^{* *}$ \\
Tissue N & Tissue C & $0.35^{*}$ & $0.67 * *$ \\
Tissue N & Total pigments & $0.57^{* *}$ & $0.73^{* * *}$ \\
\hline
\end{tabular}

Significant correlations are denoted: $* P<0.05 ; \quad * * P<0.01$; $* * * P<0.001$; ns not significant.

was found between dissolved inorganic nitrogen (DIN) and tissue $\mathrm{N}$ for Ulva spp. but not for C. linum (Table 1). Tissue $\mathrm{P}$ in Ulva spp. showed a significant negative correlation with dissolved inorganic phosphorus (DIP), the correlation for $C$. linum was insignificant. Tissue $\mathrm{N}$ and $\mathrm{P}$ and tissue $\mathrm{N}$ and $\mathrm{C}$ were positively correlated in both species.

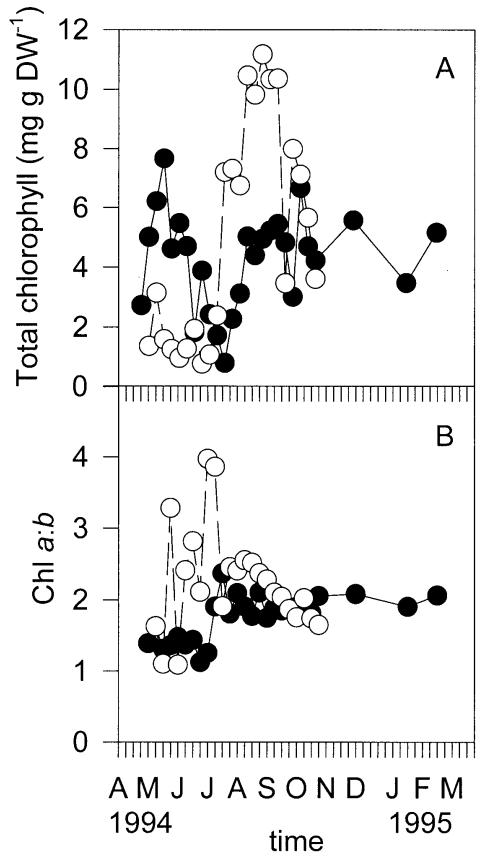

Fig. 5 Total tissue chlorophyll content (A) and chlorophyll $a: b$ ratio (B) of Ulva spp. at Middelplaten (closed circles, full line) and Chaetomorpha linum (open circles, dotted line) at Kwistenburg in the Veerse Meer (The Netherlands) from April 1994 until March 1995. Vertical lines on $x$-axis represent weeks

Total chlorophyll contents of Ulva spp. rapidly decreased to less than $1.5 \mathrm{mg} \mathrm{g} \mathrm{DW}^{-1}$ during the build-up phase, increased again in August, and remained stable for the rest of the observation period (Fig. 5A). The chlorophyll $a: b$ ratio increased from an initial 1.1-1.3 to $1.8-2.3$ during the remaining period (Fig. 5B). For C. linum, total chlorophyll levels were around 1.5$2.0 \mathrm{mg} \mathrm{g} \mathrm{DW}^{-1}$ at the beginning of the build-up phase and increased six-fold in July and August, followed by a period of high values (Fig. 5A). During the decomposition phase, total chlorophyll content decreased again. The chlorophyll $a: b$ ratio showed large fluctuations, reached a maximum value of 4.0 in spring and decreased again to approximately $1.8-2.0$ in autumn and winter (Fig. 5B). A significant positive correlation was found between total chlorophyll content and tissue $\mathrm{N}$ content in both species (Table 1).

\section{Environmental parameters}

Annual average water temperature, salinity, $\mathrm{pH}$, attenuation coefficient $(k)$, chlorophyll levels and oxygen did not differ significantly between sites (Table 2). Chlorophyll $a$ levels in the water in 1994/1995 were always below $10 \mathrm{mg} \mathrm{m}^{-3}$ for both sites, apart for two peak values in April and the beginning of May (values up to $50.5 \mathrm{mg}$ $\mathrm{m}^{-3}$ for Middelplaten and $100 \mathrm{mg} \mathrm{m}^{-3}$ for Kwistenburg). Dissolved oxygen levels showed minimal fluctuations, except for peaks in April and October 1994 and one in March 1995, occurring at both sites at the same time. 
Table 2 Ranges and means $( \pm \mathrm{SD})$ of water column parameters at two sites in the Veerse Meer (The Netherlands) from April 1994 to April 1995. Temperature is water surface temperature, $k$ is attenuation coefficient, $n=32$ for all variables except for $\mathrm{pH}(n=29)$ and $k$ $(n=27)$

\begin{tabular}{llcc}
\hline & & Middeplaten & Kwistenburg \\
\hline Temperature $\left({ }^{\circ} \mathrm{C}\right)$ & Range & $5.9-24.1$ & $5.9-24.1$ \\
& Mean & $13.8 \pm 4.2$ & $13.8 \pm 4.2$ \\
Salinity (psu) & Range & $9.6-17.4$ & $10.9-17.5$ \\
& Mean & $14.6 \pm 1.4$ & $15.0 \pm 1.3$ \\
$\mathrm{pH}$ & Range & $7.9-8.9$ & $8.1-8.8$ \\
& Mean & $8.6 \pm 0.1$ & $8.5 \pm 0.1$ \\
Seston $\left(\mathrm{mg}^{-1}\right)$ & Range & $5.6-45.0$ & $6.6-27.1$ \\
& Mean & $12.6 \pm 4.3$ & $11.7 \pm 3.5$ \\
$k\left(\mathrm{~m}^{-1}\right)$ & Range & $0.5-2.2$ & $0.4-1.6$ \\
& Mean & $0.9 \pm 0.3$ & $1.0 \pm 0.3$ \\
Planktonic chlorophyll & Range & $0.9-30.4$ & $1.1-59.6$ \\
$\left(\mathrm{mg} \mathrm{m}^{-3}\right)$ & Mean & $7.0 \pm 6.6$ & $8.3 \pm 10.1$ \\
Oxygen $\left(\mathrm{mg} \mathrm{l}^{-1}\right)$ & Range & $6.6-23.6$ & $6.6-22.3$ \\
& Mean & $11.2 \pm 0.1$ & $9.6 \pm 0.2$ \\
\hline
\end{tabular}

Table 3 Partial regression coefficients and ANOVA test results of stepwise multiple regression analysis relating growth rate of Ulva spp. in the Veerse Meer (The Netherlands) in 1994 to: water column parameters [dissolved inorganic nitrogen (DIN), dissolved inorganic phosphate (DIP), salinity, temperature and light at middepth] at Middelplaten (1) and Kwistenburg (5); water column
The April peak coincided with a phytoplankton bloom, the other two were observed immediately after the change in the water level. At both sites, the raising of the water level had a significant effect on salinity ( $t$-test, $P<0.001)$ and seston levels $(t$-test, $P<0.001)$.

Dissolved inorganic phosphate (DIP) levels increased during macroalgal biomass build-up and decreased again during the decomposition phase (Fig. 6A). Concentrated agricultural run-off after heavy rainfall probably caused the peak value at both sites in September 1994. Total dissolved inorganic nitrogen (DIN) levels increased during the decomposition phase, followed by a sharp decline during the build-up phase, leading to low values (Fig. 6B). The significant negative correlation coefficients between DIN and DIP at both sites clearly express these contrasting patterns (Table 1). A peak value for DIN was observed in October. High DIN values (over $200 \mu \mathrm{M}$ ) were reached in winter 1995 at both sites. During the build-up phase, DIN consisted mainly of ammonium (70-100\% of DIN) at both sites, while during the rest of the year nitrate+nitrite were the main constituents of the DIN (80-95\%). Mean annual

\begin{tabular}{|c|c|c|c|}
\hline 1 & Dependent variable & 2 & Dependent variable \\
\hline Independent variables & Ulva spp. growth Middelplaten & Independent variables & Ulva spp. growth Middelplaten \\
\hline Constant & $0.74 * * *$ & constant & $0.17 *$ \\
\hline DIN & ns & DIN & ns \\
\hline DIP & $-0.22 * *$ & temperature & $-0.02 * *$ \\
\hline Salinity & $-0.03 *$ & light & $0.001 * *$ \\
\hline Temperature & ns & & \\
\hline Light & ns & & \\
\hline$F$ & $17.42 * * *$ & $F$ & $7.45 * *$ \\
\hline$R^{2}$ & 0.59 & $R^{2}$ & 0.36 \\
\hline 3 & Dependent variable & 4 & Dependent variable \\
\hline Independent variables & Ulva spp. growth Middelplaten & Independent variables & Ulva spp. growth Middelplaten \\
\hline Constant & $0.86 * * *$ & Constant & ns \\
\hline Tissue N & ns & Tissue N & $0.28 *$ \\
\hline Tissue $\mathrm{P}$ & $0.36 * *$ & Temperature & $-0.01 *$ \\
\hline Salinity & $-0.03 * *$ & Light & $0.002 * * *$ \\
\hline Temperature & ns & & \\
\hline Light & ns & & \\
\hline$F$ & $22.24 * * *$ & $F$ & $7.08 * *$ \\
\hline$R^{2}$ & 0.65 & $R^{2}$ & 0.44 \\
\hline 5 & Dependent variable & 6 & Dependent variable \\
\hline Independent variables & Ulva spp. growth Kwistenburg & Independent variables & Ulva spp. growth Kwistenburg \\
\hline Constant & $1.39 * * *$ & Constant & ns \\
\hline DIN & ns & DIN & $0.08^{* * *}$ \\
\hline DIP & ns & Temperature & ns \\
\hline Salinity & $-0.07 * * *$ & Light & $0.001 *$ \\
\hline Temperature & $-0.01 * *$ & & \\
\hline Light & ns & & \\
\hline$F$ & $35.76 * * *$ & $F$ & $7.76 * *$ \\
\hline$R^{2}$ & 0.75 & $R^{2}$ & 0.37 \\
\hline
\end{tabular}

Significant partial regression coefficients and $F$ values are marked: $* P<0.05 ; * * P<0.01 ; * * * P<0.001$; ns not significant. 


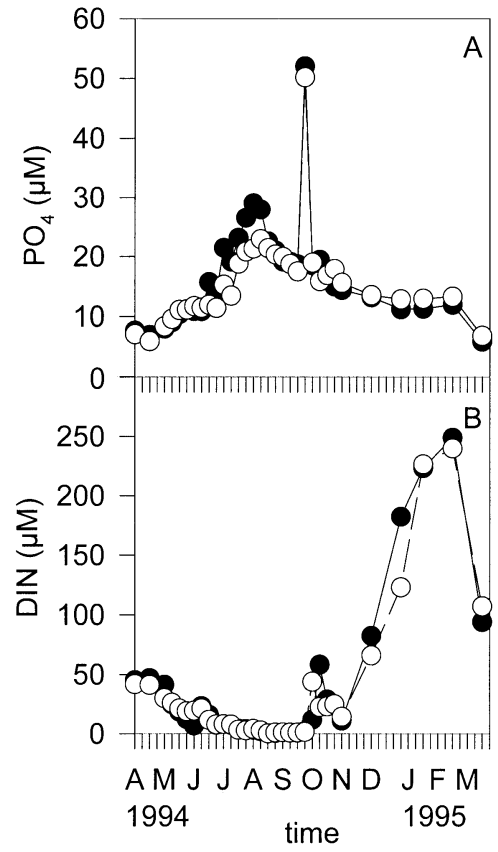

Fig. 6a, b Nutrient concentrations in the surface water of the Veerse Meer (The Netherlands) at Middelplaten (closed circles, full line) and Kwistenburg (open circles, dotted line) from April 1994 until March 1995. A Total inorganic phosphorus (DIP, $\mu M$ ); B dissolved inorganic nitrogen (DIN, $\mu \mathrm{M})$. Vertical lines on $x$-axis represent weeks

DIN and DIP concentrations were not significantly different between sites.

Relations of environmental parameters and tissue nutrient levels with growth rates

Testing the simultaneous effects of all environmental parameters on weekly average growth of Ulva spp. with a multiple regression analysis resulted in a negative partial correlation of growth with salinity and DIP, explaining $59 \%$ of the variation (Table 3 ). Leaving out salinity and DIP (as explained in Discussion) resulted in a negative partial correlation of growth with temperature and a positive correlation with light, explaining $36 \%$ of the variation. Replacement of the water nutrient concentrations (DIN and DIP) by tissue $\mathrm{N}$ and tissue $\mathrm{P}$ (as explained in Discussion) returned a positive partial correlation with tissue $\mathrm{P}$ and a negative correlation with salinity, explaining $65 \%$ of the variation. When tissue $\mathrm{P}$ and salinity were excluded, $44 \%$ of the variation was explained by tissue $\mathrm{N}$ (positive), temperature (negative) and light (positive).

At Kwistenburg, a negative partial correlation with salinity and temperature explained $75 \%$ of the variation. When salinity and DIP were excluded, $37 \%$ of the variation was explained by DIN (positive) and light (positive). Testing of the different cage compartments gave similar results for both sites.

\section{Discussion}

Algal biomass distribution

The occurrence of large differences between sites in species distribution and biomass has been reported earlier and could in some cases be attributed to environmental parameters, such as salinity, nutrient loading and turbidity (Josselyn and West 1985; Thom and Albright 1990; Brouwer et al. 1995; Valiela et al. 1997). Spatial differences are in these studies mainly attributed to better environmental conditions for macroalgal growth; however, actual growth rates or daily biomass production were rarely measured. As we pointed out in the Introduction, simultaneous measurements of growth rates and biomass development will reveal whether growth or loss processes are responsible for spatial differences: a lack of difference in growth rates but large differences in biomass implies the loss of biomass. In the Veerse Meer, growth rates at Kwistenburg were equal to those at Middelplaten during most of the season and even higher in May and June (Fig. 4), while biomass was much lower at Kwistenburg. Hence we conclude that biomass loss processes caused the spatial heterogeneity in the Veerse Meer. Similar conclusions were drawn for Ulva spp. biomass at sites in the lagoon of Venice, Italy (Sfriso 1995) and the Palmones estuary, Spain (Hernández et al. 1997).

The most important loss processes for macroalgal biomass are decomposition (Sfriso 1995), grazing (GeertzHansen et al. 1993) and transport by waves and wind (Lowthion et al. 1985; Soulsby et al. 1985; Vergara et al. 1997). Anoxic conditions, which often occur in dense mats, accelerate algal die-off and thereby elevate decomposition rates (De Casabianca-Chassany 1989). One would thus expect that the site with the highest biomass (Middelplaten) would be more sensitive to these processes, which makes them unlikely causes of the difference between the sites. It has been shown that grazing by invertebrates and birds can reduce macroalgal biomass considerably (Coosen et al. 1990; Seys et al. 1991; Geertz-Hansen et al. 1993; Horne et al. 1994). Experiments carried out by Kamermans et al. (2002), however, show that there is a low grazing pressure on invertebrates in the Veerse Meer, which does not differ between sites. Moreover, they showed that invertebrates can even have a stimulating effect on macroalgal growth by clearing Ulva thalli of diatoms. Bird grazing takes place mainly during the late summer and autumn when the difference between sites is already evident; thus we assume that grazing was also not responsible for the observed difference. Several authors have suggested the importance of wind and currents as important factors for transport of free-floating macroalgae (Flindt et al. 1997; Hernández et al. 1997; Salomonsen et al. 1997). In the Veerse Meer, transport from the more exposed site at Kwistenburg may be more important as a loss factor than at Middelplaten. Wind-driven transport may also explain the marked increase in autumn at both sites. Future research should examine and quantify the role of transport, 
to better understand both the spatial and seasonal dynamics of macroalgal biomass.

Seasonal variation, relation with environmental parameters

Roughly, three to four phases in the Ulva spp. biomass dynamics could be distinguished in the Veerse Meer: a period without biomass, a period of rapid growth and biomass increase, followed by a more stationary period and finally a period in which biomass disappears again. From December to May there is no above-ground biomass at all. Kamermans et al. (1998) have shown that during this phase Ulva spp. fragments survive buried in the sediment. Viable remainders of these fragments can initiate the spring biomass build-up, so we can speak of a dormant phase. Temperature, wind (to uncover the buried thalli) and probably also light (both intensity and day length) are the variables that determine the onset of growth (Kamermans et al. 1998).

Multiple regressions explained a limited, but significant, part of the variation in cage growth rates during the rest of the year. Tissue nutrient concentrations proved to be better in accounting for the variation in Ulva growth than nutrients in the water. This can be explained by the capacity of Ulva spp. for luxury uptake and storage of nutrients. When nutrient concentrations in the water decrease, the algae can then grow on their internal reserves (Fujita 1985; Viaroli et al. 1996; Pedersen and Borum 1997). However, the results should be interpreted with care, as intercorrelation of the independent variables can greatly influence the outcome of a multiple regression analysis (Robertson et al. 1993; Sokal and Rohlf 1995). It is very likely that the correlations with phosphate/tissue $\mathrm{P}$ and salinity are the result of these intercorrelations and have no causal meaning. Both DIP and salinity increased during the year. Considering the concentrations and the negative correlation of phosphorus with tissue $\mathrm{P}$ for Ulva at Middelplaten, neither phosphorus limitation nor phosphorus toxification seem a likely cause of variation in Ulva spp. growth in the Veerse Meer. A negative effect of increasing salinity is very unlikely, as the optimum salinity for growth of Ulva spp. is still higher than that observed in the Veerse Meer (Bliding 1968; Koeman and Van den Hoek 1981; Dickson et al. 1982).

For the reasons explained above, we excluded phosphorus and salinity from the analysis, which resulted in a positive relation of growth with tissue $\mathrm{N}$ and light and a negative relation with temperature. The degree to which an alga is nitrogen-limited can be determined by comparing the observed tissue $\mathrm{N}$ levels of the algae with the socalled critical tissue $\mathrm{N}$ levels determined in experimental set-ups (i.e. the nitrogen level below which growth rates decrease; Morand and Briand 1996). Critical values determined for Ulva spp. range from $2.0 \%$ to $2.4 \%$ DW (Fujita et al. 1989; Lavery and McComb 1991; Pedersen 1994). As tissue N levels of Ulva spp. at Middelplaten were close to or below the critical values at the end of the build-up phase, it is concluded that nitrogen limitation may have occurred during this period, causing the transition from the build-up period to a more stationary period. The increase in tissue nitrogen during the stationary and the decomposing phase is probably mainly due to the leakage of nitrogen-free compounds from decomposing thalli (Hanisak 1993; Viaroli et al. 1996). However, self-shadowing, leading to strong light limitation and luxury uptake of nitrogen, may also increase the average tissue $\mathrm{N}$ of a dense algal mat, as suggested by Vergara et al. (1998). Studies on such vertical gradients in macroalgal mats are very rare; however, they certainly deserve more attention as they can be helpful in explaining some components of the complex dynamics of macroalgal biomass (Vergara et al. 1998 and references therein; Malta 2000). Although tissue $\mathrm{N}$ data for Ulva spp. at Kwistenburg were not available, the results of the multiple regression analysis and the observed similar pattern in seasonal variation in growth suggest that here also nitrogen has been limiting for some part of the season.

Light and temperature also showed a significant correlation with growth, supporting the earlier conclusion that light was the main growth-limiting variable during the build-up phase (Malta and Verschuure 1997). Both the higher growth rates in the upper cage compartments during the first weeks of the season and the observed low chlorophyll $a: b$ ratio and the high total chlorophyll content of Ulva spp. in spring support their conclusion (Ramus et al. 1976; Henley and Ramus 1989). Temperature may have affected growth rates in two ways. High water temperatures (over $20^{\circ} \mathrm{C}$ ) have been shown to inhibit growth in Ulva lactuca from the North Sea (Fortes and Lüning 1980), although Malta et al. (1999) still found high growth rates for $U$. scandinavica from the Veerse Meer at $25^{\circ} \mathrm{C}$. Another way in which temperature can affect the biomass variation is by stimulating respiration, causing temporal anoxia, resulting in die-off and decomposition (Sfriso et al. 1987). We observed indications of anoxia - black sediment and sulphuric smell (E.-j. Malta and J.M. Verschuure, personal observation) - at both sites in the Veerse Meer. In this way, temperature-enhanced decomposition, possibly together with bird grazing, could be the variables that determine the transition from the stationary phase to the decomposition phase.

If and to what extent growth of $C$. linum is regulated by the same parameters of Ulva spp. remains unclear. The tissue $\mathrm{N}$ of $C$. linum in Veerse Meer was always well above the critical value of $1.15 \%$ DW found by Pedersen and Borum (1996), so we conclude that growth of $C$. linum was not nitrogen-limited. Light might have been limiting during the build-up phase, considering the low chlorophyll $a: b$ ratios. The thick mats of $C$. linum started decomposing in October-November and were totally anoxic at certain locations, leading to the formation of $\mathrm{H}_{2} \mathrm{~S}$ and elemental sulphur in the water column (E.-j. Malta, personal observation). This, most probably, has led to the final decline of the alga. 


\section{Conclusions}

This study has demonstrated that measurements of in situ growth and/or production rates are of vital importance in revealing the mechanisms that are responsible for the observed spatial and seasonal variation of macroalgal biomass. In the Veerse Meer, growth was not found to be responsible for spatial heterogeneity in macroalgal biomass. Future studies should pay special attention to loss processes in macroalgal populations, especially to windand current-driven transport.

Acknowledgements The authors thank J.W. Rijstenbil and P. Kamermans and two anonymous referees for their comments on earlier drafts of this manuscript. Thanks are due to the personnel of the Laboratory for Sediment and Particle Analysis and of the Laboratory for Water Analysis of the NIOO-CEMO for carrying out the analyses. Peter van Breugel and Edwin Arens helped with the analyses and with the fieldwork. Herre Stegenga of the Rijksherbarium in Leiden kindly provided identifications of the algae. This study was carried out within the framework of the EUMAC project. EUMAC is funded by the Environment and Climate programme of the European Commission (no. EV5VCT93-0290). This is NIOO publication no. 3033

\section{References}

Barthelemy N, Serrano O, Posada F, De Casabianca ML, Sfriso A (2001) Role of abiotic factors on the growth of Ulva rigida from two southern sites. Vie Milieu 51:21-28

Bliding C (1968) A critical survey of European taxa in Ulvales. II. Ulva, Ulvaria, Monostroma, Kornmannia. Bot Not 121:535629

Brouwer PEM, Geilen EFM, Gremmen NJM, Van Lent F (1995) Biomass, cover and zonation pattern of sublittoral macroalgae at Signy Island, South Orkney Islands, Antarctica. Bot Mar 38:259-270

Brown LM, Hargrave BT, MacKinnon MD (1981) Analysis of chlorophyll $a$ in sediments by high pressure liquid chromatography. Can J Fish Aquat Sci 38:205-214

Brown VB, Davies SA, Synnot RN (1990) Long-term monitoring of the effects of sewage effluent on intertidal macroalgae. Bot Mar 33:85-98

Chen PS (1956) Microdetermination of phosphorus. Anal Chem 28:1756-1758

Coosen J, Meire P, Stuart JJ, Seys J (1990) Trophic relationships in brackish Lake Veere: the role of macrophytes. In: Barnes M, Gibson RN (eds) Trophic relationships in the marine environment. Proceedings of the 24th European marine biology symposium. Aberdeen University Press, Aberdeen, pp 404-424

De Casabianca-Chassany ML (1989) Dégradation des ulves (Ulva rotundata, lagune du Prévost, France). C R Acad Sci Paris 308:155-160

Dickson DMJ, Wyn Jones RG, Davenport J (1982) Osmotic adaptation in Ulva lactuca under fluctuating salinity regimes. Planta 155:409-415

Duarte CM (1995) Submerged aquatic vegetation in relation to different nutrient regimes. Ophelia 41:87-112

EUMAC (1994) Eutrophication and macrophytes. (Comparative studies into the dynamics of the impact of marine eutrophication on benthic macrophytes in different European coastal waters) Nederlands Instituut voor Oecologisch Onderzoek/ Centrum voor Estuariene en Mariene Oecologie, Yerseke, The Netherlands

Flindt M, Salomonsen J, Carrer M, Bocci M, Kamp-Nielsen L (1997) Loss, growth and transport dynamics of Chaetomorpha aerea and Ulva rigida in the Lagoon of Venice during an early summer field campaign. Ecol Model 102:133-141
Fortes MD, Lüning K (1980) Growth rates of North Sea macroalgae in relation to temperature, irradiance and photoperiod. Helgol Meeresunters 34:15-29

Fujita RM (1985) The role of nitrogen status in regulating transient ammonium uptake and nitrogen storage by macroalgae. J Exp Mar Biol Ecol 92:283-301

Fujita RM, Wheeler PA, Edwards RL (1989) Assessment of macroalgal nitrogen limitation in a seasonal upwelling region. Mar Ecol Prog Ser 53:293-303

Geertz-Hansen O, Sand-Jensen K, Hansen DF, Christiansen A (1993) Growth and grazing control of abundance of the marine macroalga, Ulva lactuca L. in a eutrophic Danish estuary. Aquat Bot 46:101-109

Grasshof K, Ehrhardt M, Kremling K (1983) Methods of seawater analysis. Verlag Chemie, Weinheim

Hanisak MD (1993) Nitrogen release from decomposing seaweeds: species and temperature effects. J Appl Phycol 5:175181

Hannewijk A (1988) De verspreiding en biomassa van macrofyten in het Veerse Meer, 1987 Rapporten en verslagen 1988-2. Delta Instituut voor Hydrobiologisch Onderzoek, Yerseke, The Netherlands

Hein M, Pedersen MF, Sand-Jensen K (1995) Size-dependent nitrogen uptake in micro- and macroalgae. Mar Ecol Prog Ser 118:247-253

Henley WJ, Ramus J (1989) Optimization of pigment content and the limits of photoacclimation for Ulva rotundata (Chlorophyta). Mar Biol 103:267-274

Hernández I, Peralta G, Pérez-Lloréns JL, Vergara JJ, Niell FX (1997) Biomass and dynamics of growth of Ulva species in Palmones river estuary. J Phycol 33:764-772

Horne A, McClelland J, Valiela I (1994) The growth and consumption of macroalgae in estuaries: the role of invertebrate grazers along a nutrient gradient in Waquoit Bay, Massachusetts. Biol Bull 187:279-280

Jerlov NG (1970) Light: general introduction. In: Kinne O (ed) Marine ecology: environmental factors. Wiley, London, pp 95-102

Josselyn MN, West JA (1985) The distribution and temporal dynamics of the estuarine macroalgal community of San Fransisco Bay. Hydrobiologia 129:139-152

Kamermans P, Malta E-j, Verschuure JM, Lentz LF, Schrijvers L (1998) Role of cold resistance and burial for winter survival and spring initiation of an Ulva spp. (Chlorophyta) bloom in a eutrophic lagoon (Veerse Meer lagoon, the Netherlands). Mar Biol 131:45-51

Kamermans P, Malta E-j, Verschuure JM, Schrijvers L, Lentz LF, Tjin A Lien A (2002) Effect of grazing by isopods and amphipods on growth of Ulva spp. (Chlorophyta). Aquat Ecol 36:425-433

Koeman RPT, Van den Hoek C (1981) The taxonomy of Ulva (Chlorophyceae) in The Netherlands. Br Phycol J 16:9-53

Lavery PS, McComb AJ (1991) The nutritional eco-physiology of Chaetomorpha linum and Ulva rigida in Peel Inlet, Western Australia. Bot Mar 34:251-260

Littler MM, Littler DS (1980) The evolution of thallus form and survival strategies in benthic marine macroalgae: field and laboratory tests of a functional form model. Am Nat 116:25-44

Lowthion D, Soulsby PG, Houston M (1985) Investigation of a eutrophic tidal basin. Part 1. Factors affecting the distribution and biomass of macroalgae. Mar Environ Res 15:263-284

Malta E-j (2000) Macroalgal mats in a eutrophic lagoon: dynamics and control mechanisms. PhD dissertation, University of Nijmegen, The Netherlands

Malta E-j, Verschuure JM (1997) Effects of environmental variables on between-year variation of Ulva growth and biomass in a eutrophic brackish lake. J Sea Res 38:71-84

Malta E-j, Draisma SGA, Kamermans P (1999) Free-floating Ulva in the southwest Netherlands: species or morphotypes? A morphological, molecular and ecophysiological comparison. Eur J Phycol 34:443-454 
Morand P, Briand X (1996) Excessive growth of macroalgae: a symptom of environmental disturbance. Bot Mar 39:491-516

Nienhuis PH (1989) Eutrophication of estuaries and brackish lagoons in the South-west Netherlands. In: Hooghart JC, Posthumus CWS (eds) Hydro-ecological relations in the deltawaters of the south-west Netherlands. (Technical meeting 46 Rotterdam, The Netherlands, 8 March, 1989) TNO Committee on Hydrological Research, The Hague, The Netherlands

Nienhuis PH (1992) Ecology of coastal lagoons in The Netherlands (Veerse Meer and Grevelingen). Vie Milieu 42:59-72

Nieuwenhuize JC, Poley-Vos C (1989) A rapid microwave dissolution method for the determination of trace and minor elements in lyophilized plant material. At Spec 45:217-224

Pedersen MF (1994) Vaekst og naeringsdynamik hos marine planter. PhD dissertation, University of Copenhagen, Denmark

Pedersen MF, Borum J (1996) Nutrient control of algal growth in estuarine waters: nutrient limitation and the importance of nitrogen requirements and nitrogen storage among phytoplankton and species of macroalgae. Mar Ecol Prog Ser 142:261-272

Pedersen MF, Borum J (1997) Nutrient control of estuarine macroalgae: growth strategy and the balance between nitrogen requirements and uptake. Mar Ecol Prog Ser 161:155-163

Ramus J, Beale SI, Mauzerall D, Howard KL (1976) Changes in photosynthetic pigment concentration in seaweeds as a function of water depth. Mar Biol 37:223-229

Robertson PA, Woodburn MIA, Hill DA (1993) Factors affecting winter pheasant density in British woodlands. J Appl Ecol 30:459-464

Salomonsen J, Flindt MR, Geertz-Hansen O (1997) Significance of advective transport of Ulva lactuca for a biomass budget on a shallow water location. Ecol Model 102:129-132

Sand-Jensen K, Borum J (1991) Interactions among phytoplankton, periphyton, and macrophytes in temperate freshwaters and estuaries. Aquat Bot 41:137-175

Schramm W, Nienhuis PH (1996) Marine benthic vegetation: recent changes and the effect of eutrophication. (Ecological studies vol 123) Springer, Berlin Heidelberg New York

Seys J, Van Lent F, Meire P (1991) Zeesla en bodemdieren in het Veerse Meer. Levende Nat 92:52-56

Sfriso A (1995) Temporal and spatial responses of growth of Ulva rigida $\mathrm{C}$. Ag. to environmental and tissue concentrations of nutrients in the lagoon of Venice. Bot Mar 38:557-573
Sfriso A, Marcomini A (1997) Macrophyte production in a shallow coastal lagoon. 1. Coupling with chemical-physical parameters and nutrient concentrations in waters. Mar Environ Res 44:351-375

Sfriso A, Marcomini A, Pavoni B (1987) Relationships between macroalgal biomass and nutrient concentrations in a hypertrophic area of the Venice Lagoon. Mar Environ Res 22:297-312

Sokal RR, Rohlf FJ (1995) Biometry, 3rd edn. W.H. Freeman, New York

Soulsby PG, Lowthion D, Houston M, Montgomery HAC (1985) The role of sewage effluent in the accumulation of macroalgal mats on intertidal mudflats in two basins in Southern England. Neth J Sea Res 19:257-263

Tewari A, Joshi HV (1988) Effect of domestic sewage and industrial effluents on biomass and species diversity of seaweeds. Bot Mar 31:389-397

Thom RM, Albright RG (1990) Dynamics of benthic vegetation standing-stock, irradiance, and water properties in central Puget Sound. Mar Biol 104:129-141

Thorne-Miller B, Harlin MM, Thursby GB, Brady-Campbell MM, Dworetzky BA (1983) Variations in the distribution and biomass of submerged macrophytes in five coastal lagoons in Rhode Island, USA. Bot Mar 26:231-242

Valiela I, McClelland J, Hauxwell J, Behr PJ, Hersh D, Foreman K (1997) Macroalgal blooms in shallow estuaries: controls and ecophysiological and ecosystem consequences. Limnol Oceanogr 42:1105-1118

Van Lent F, Verschuure JM (1994) Intraspecific variability of Zostera marina L. (eelgrass) in the estuaries and lagoons of the southwestern Netherlands. I. Population dynamics. Aquat Bot 48:31-58

Vergara JJ, Pérez-Lloréns JL, Peralta G, Hernández I, Niell FX (1997) Seasonal variation of photosynthetic performance and light attenuation in Ulva canopies from Palmones river estuary. J Phycol 33:773-779

Vergara JJ, Sebastián M, Pérez-Lloréns JL, Hernández I (1998) Photoacclimation of Ulva rigida and $U$. rotundata (Chlorophyta) arranged in canopies. Mar Ecol Prog Ser 165:283-292

Viaroli P, Naldi M, Bondavalli C, Bencivelli S (1996) Growth of the seaweed Ulva rigida $\mathrm{C}$. Agardh in relation to biomass densities, internal nutrient pools and external nutrient supply in the Sacca di Goro lagoon (Northern Italy). Hydrobiologia 329:93-103 